\title{
ISLAM DAN PEMBANGUNAN MANUSIA DI ERA GLOBALISASI
}

\author{
As'ad Bukhari \\ Pascasarjana UIN Sunan Kalijaga Yogyakarta 555181, Indonesia \\ smash.azza@gmail.com
}

Received : $\quad$; Accepted : ;Published :

\begin{abstract}
In the globalization era, people are increasingly competitive and increasing their ability to become productive human beings. Human development is the main thing in doing change and progress in life. In the discussion Human development in the era of globalization which is a world program through the unity of nations is inseparable from the study of Islam. So that Islam as a religion can enter to become a very important discussion in development issues of course. National development becomes the main task of the government from the regional level to the province, thus providing human resources as a form of mover and its managers. Policies on human resource development always experience dynamics and perkembangnnya in terms of sociology, anthropology and culture. Islam as the majority religion in Indonesia becomes a determinant and has a major influence on development issues nationally. Islam and human development in the era of globalization becomes the most important thing to build Indonesia into a culture, character and progress. Thus the development process becomes the main part to reconstruct the infrastructure, human, network and every aspect. Construction in religious thought that is the study of Islamic thought in the development process becomes the goal for tercipatanya development in the era of globalization. It is also a form of advancing the society and mindset of a digitally literate man and aware of science, technology, development and life in the era of globalization in the form of international relations.
\end{abstract}

Keywords: Construction Of Islamic, Human Development

Di era globalisasi ini yang sering disebut era modernisasi ini sangat diperlukan sumber daya manusia yang sangat memadai untuk perkembangan dikalangan masyarakat Indonesia yang masih jauh dari harapan pemerintah sebagai pengatur tatanan pemerintah maupun tatanan masyarakatnya yang bertujuan untuk memakmurkan dan mensejahterakan kehidupan berbangasa dan bernegara. Standar pembangunan manusia yang menjadi kesepakatan antara lain 
berhak untuk bisa membaca dan menulis, untuk hidup sehat, untuk bisa mendapatkan penghasilan yang layak, untuk mendapat rumah yang memadai, dan untuk hidup sebagai satu bangsa dengan damai dan aman. Diharapkan dengan desentralisasi atau yang lebih populer disebut otonomi daerah dapat memotivasi daerah-daerah tingkat propinsi maupun kabupaten/kota untuk lebih memprioritaskan mengurangi kemiskinan dan mempersiapkan diri dalam sumber daya manusia yang handal.

Paradigma pembangunan manusia melihat bahwa usaha peningkatan kualitas manusia memiliki nilai intrinsik, dalam arti, sebagai tujuan pada dirinya sendiri. Prespektif ini berbeda dengan pembangunan sumber daya manusia, yang menempatkan manusia sebagai sumber atau input pembangunan dan melihat kualitas manusia sebagai sarana (means) untuk menghasilkan pendapatan. Sebagai paradigma pembangunan yang holistik, pembangunan manusia memandang program pembangunan yang dirancang, seharusnya bercirikan "of, for and by people". Maksud dari ciri-ciri ini adalah sebagai berikut: Pertama, tentang penduduk (of people), yakni pemberdayaan penduduk yang diupayakan melalui investasi bidang-bidang pendidikan kesehatan, dan pelayanan sosial dasar lainnya: Kedua, untuk penduduk (for people), yakni pemberdayaan penduduk yang diupayakan melalui penciptaan peluang kerja dan perluasan peluang berusaha (dengan cara memperluas kegiatan ekonomi suatu wilayah): Ketiga, oleh penduduk (by people), yakni pemberdayaan penduduk yang dapat meningkatkan harkat dan martabat melalui partisipasi dalam pengambilan keputusan di segala bidang. Dalam hal ini berarti menyangkut pengambilan keputusan dalam proses pembangunan.

Keberhasilan masa depan suatu daerah di era globalisasi terletak pada pengelolaan produktifitas, pengusahaan perubahan-perubahan dan pengelolaan pembangunan kerja secara cepat. Masyarakat kita tergantung pada spesialisasi dari berbagai spesifik untuk menyediakan output dan input yang dihasilkan maupun yang didapat supaya menghindari pengangguran berstruktur, sehingga menaikan kualitas taraf hidup subjek atau masyarakat sekaligus mengurangi angka pengangguaran disuatu daerah. Demi mencapai kehidupan yang lebih baik 


\section{3}

diperlukan proses sosial antara pemerintah dan masyarakatnya demi mencapai keselarasan dan keseimbangan antara tujuan yang ingin dicapai oleh pemerintah maupun tujuan yang ingin dicapai oleh masyarakat. Apapun komponen spesifik atas kehidupan yang lebih baik itu, pembangunan di semua masyarakat paling tidak memiliki tiga tujuan inti yaitu peningkatan ketersediaan kebutuhan pokok, peningkatan standar hidup, dan perluasan pilihan ekonomis dan sosial setiap individu. Adanya kemiskinan di dalam suatu wilayah merupakan potret bahwa pembangunan itu secara umum kurang berhasil sehingga pada dasarnya keberhasilan pembangunan suatu wilayah tergantung pada kegiatan pembangunan dan pemerataan hasil-hasilnya. Globalisasi selalu berkaitan dengan perekonomian yang melibatkan hubungan-hubungan global. Sesungguhnya globalisasi bukan hanya sebatas tentang kesalingtergantungan terhadap ekonomi saja, akan tetapi terletak pada persoalan transformasi waktu dan ruang dalam kehidupan manusia. Globalisasi dapat mempengaruhi masyarakat secara langusng dan segera dibandingkan dengan peristiwa-peristiwa sebelumnya. Hal ini tidak lepas dari jasa revolusi komunikasi dan peyebaran teknologi informasi yang semakin cepat, canggih dan modern.

Indeks pembangunan manusia merupakan cara sebuah negara adalah negara maju, negara berkembang atau negara terbelakang dan juga untuk mengukur pengaruh dari kebijaksanaan ekonomi terhadap kualitas hidup. Pembangunan manusia, dalam terminologi pembangunan di Indonesia bukanlah suatu hal yang baru. Dalam berbagai dokumen perencanaan pembangunan maupun retorika politik pembangunan, hal tersebut sering dijumpai dalam berbagai kesempatan. Namun demikian, selama enam repelita, pembangunan manusia kurang mendapatkan perhatian yang memadai. Kini, setelah derasnya arus reformasi dan tuntutan krisis tak lagi dapat terbendung, banyak orang kembali mengangkat isu tentang hakekat pembangunan yang selama ini dilaksanakan, yang konon tidak terpusat pada manusia sebagaimana dikehendaki oleh paradigma baru pembangunan manusia. 


\section{METODE}

Pembangunan sumber daya manusia merupakan salah satu modal dalam pembangunan Negara yang prinsip dasarnya ialah pendidikan sebagai bentuk peningkatan terhadap peradaban manusia. Islam memberikan metode untuk menerapakan pembangunan manusia dengan beberapa faktor mulai dari kecerdasan spiritual (akal), akhlakul karimah (perbuatan), dan pondasi tauhid (hati). Sedangkan metode pembangunan manusia di era globalisasi menggunakan beberapa faktor mulai dari kecerdasan intelektual, kecerdasan emosional, kecerdasan spitual, kecerdasan sosial, dan kecerdasan manajerial. Tujuan dari konstruksi studi Islam dan pembangunan manusia di era globalisasi adalah terciptanya masyarakat Islam yang menerapkan nilai-nilai spititual dengan mengintegrasikan kehidupan modernitas kontemporer, sehingga sinergitas terhadap prinsip Islam dan pembangun manusia terjadi relasi kemajuan.

Metode yang dilakukan dalam kajian penelitian ini yaitu kajian pustaka, riset literatur, kualitatif-deskriptif dan analisis diskursus kontemporer. Kajian studi konstruksi Islam yang membahas tentang pembangunan manusia mengacu pada penerapan Al-Qur'an secara kontekstual, melalui interpretasi tekstual sebagai bentuk kajian pemikiran Islam era globalisasi. Pembangunan manusia di era globalisasi yang dianggap sangat liberatif dan sekuler dapat terbantahkan melalui studi konstruksi Islam. Tujuan dari pembangunan mansia menurut perspektif Islam agar supaya manusia memperoleh al-falah yaitu kejayaan dan kesejahteraan hidup di dunia dan di akhirat untuk mencapai keseimbangan hidup, ketenangan hidup serta kemajuan hidup di era globalisasi.

\section{PEMBAHASAN}

\section{DEFENISI PEMBANGUNAN MANUSIA}

Pembangunan manusia, menurut UNDP, didefinisikan sebagai suatu proses yang ditujukan untuk memperluas pilihan-pilihan bagi penduduk (people). Dalam konsep ini, penduduk (manusia) sebagai tujuan akhir (the ultimate end) dan upaya pembangunan itu sendiri sebagai sarana utama (principle means) dalam rangka mencapai tujuan itu. Untuk menjamin 
tercapainya tujuan tersebut, empat hal pokok yang perlu diperhatikan, yaitu: produktivitas, pemerataan, kesinambungan, dan pemberdayaan. Keempat hal ini, saling tertkait, dan menjadi penentu dalam perumusan kebijakan pembangunan manusia (dalam arti yang luas). Konsep pembangunan manusia dalam pengertian di atas jauh lebih luas dibandingkan dengan teori-teori pembangunan ekonomi yang konvensional termasuk model pertumbuhan ekonomi, pembangunan sumber daya manusia (SDM), pendekatan kesejahteraan, dan pendekatan kebutuhan-kebutuhan dasar manusia. Model pertumbuhan ekonomi berkaitan dengan peningkatan pendapatan dan produksi nasional (GNP). Pembangunan SDM menempatkan manusia terutama sebagai input dari proses produksi (sebagi suatu sarana bukan tujuan). Pendekatan kesejahteraan melihat manusia sebagai pemanfaat (beneficiaries) bukan sebagai agen perubahan dalam pembangunan. Pendekatan kebutuhan dasar memfokuskan pada penyediaan barang dan jasa kebutuhan hidup.

Mengenai pengertian pembangunan, para ahli memberikan definisi yang bermacam-macam seperti halnya perencanaan. Istilah pembangunan bisa saja diartikan berbeda oleh satu orang dengan orang lain, daerah yang satu dengan daerah lainnya, Negara satu dengan Negara lain. Namun secara umum ada suatu kesepakatan bahwa pembangunan merupakan proses untuk melakukan perubahan. Menurut Siagian, ia memberikan pengertian tentang pembangunan sebagai suatu usaha atau rangkaian usaha pertumbuhan dan perubahan yang berencana dan dilakukan secara sadar oleh suatu bangsa, negara dan pemerintah, menuju modernitas dalam rangka pembinaan bangsa (nation building). Sedangkan menurut Ginanjar Kartasasmita memberikan pengertian yang lebih sederhana, yaitu sebagai suatu proses perubahan ke arah yang lebih baik melalui upaya yang dilakukan secara terencana. Dengan demikian dapat dikatakan bahwa pada dasarnya pembangunan tidak dapat dipisahkan dari pertumbuhan, dalam arti bahwa pembangunan dapat menyebabkan terjadinya pertumbuhan dan pertumbuhan akan terjadi sebagai akibat adanya pembangunan. Dalam hal ini pertumbuhan dapat berupa 
pengembangan atau perluasan (expansion) atau peningkatan (improvement) dari aktivitas yang dilakukan oleh suatu komunitas masyarakat.

Sementara itu, terdapat referensi lain yang menggagas konsep dan indeks pembangunan manusia dari perspektif berbeda. Salah satunya dikemukakan oleh Stiglitz, Sen, dan Fitoussi, yang mengukur pembangunan manusia berdasarkan kesehatan, pendidikan, keamanan dari segi ekonomi, keseimbangan waktu, partisipasi politik dan pemerintahan, hubungan sosial, kondisi lingkungan, keamanan pribadi, dan tingkat kualitas kehidupan. Disisi lain, dalam penelitian yang dilakukan oleh Alkire, konsep pembangunan manusia diterangkan sebagai berikut:

Pembangunan manusia ditujukan untuk memperbesar kebebasan individu dalam melakukan dan menjadi sesuatu yang menurut mereka bernilai. Secara prinsip, pembangunan manusia semestinya memberdayakan manusia, atau dengan kata lain, pembangunan manusia semestinya menjadikan manusia sebagai fokus utama.

Pembangunan manusia mencakup kebebasan dasar yang berkaitan dengan kehidupan manusia, dan ini berlaku untuk semua Negara.

Pembangunan manusia merupakan pembangunan yang dilakukan oleh manusia, berkaitan dengan manusia, dan ditujukan untuk manusia. Dengan demikian tidak mengenal apakah manusia tersebut miskin atau kaya, serta bertindak selaku orang pribadi atau sebagai anggota komunitas masyarakat. Intinya, manusia lah yang menjadi pemeran utama.

Untuk mengukur tingkat pembangunan manusia ditetapkan skala prioritas tertentu, antara lain memasukkan faktor pengentasan kemiskinan, keadilan, efisiensi, partisipasi, kesinambungan, serta penghormatan terhadap hak asasi manusia. Pembangunan manusia bersifat multidimensional dan setiap komponen didalamnya memiliki keterkaitan. Oleh karenanya diperlukan sudut pandang yang menyeluruh (holistic) dalam memahaminya.

Paradigma pembangunan di Indonesia mengalami perkembangan dari beberapa tahap sebagai berikut: Pertama, paradigma pertumbuhan (growth paradigm): Kedua, pergeseran dari paradigma pertumbuhan menjadi 
paradigm kesejahteraan (Welfare paradigm): dan Ketiga, paradigma pembangunan yang berpusat ada manusia (people centered development paradigm). Menurut Owens (1987) yang dikutip oleh Martinus Nanang, hal terpenting adalah pembangunan manusia dan bukan pembangunan benda (the development of people rather than the development of things), karena nilai balik riil pembangunan manusia memberikan sumbangan lebih daripada pembangunan dibandingkan pada pembangunan benda (fisik). Dalam UNDP (United Nations Development Programme), pembangunan manusia adalah suatu proses untuk memperbesar pilihan-pilihan bagi manusia ("a process of enlarging people's choices"). Konsep atau definisi pembangunan manusia tersebut pada dasarnya mencakup dimensi pembangunan yang sangat luas. Dalam konsep pembangunan manusia, pembangunan seharusnya dianalisis serta dipahami dari sudut manusianya, bukan hanya dari pertumbuhan ekonominya.

\section{STUDI ISLAM TERHADAP PEMBANGUNAN MANUSIA}

Era globalisasi merupakan suatu akibat revolusi yang terjadi pada ilmu pengetahuan dan teknologi yang tidak terbendung, sehingga menimbulkan dampak positif dan negatif di dalam masyarakat. Terutama terhadap masyarakat yang sedang berkembang, sehingga dalam berbagai ilmu sosial kemasyarakatan terdapat menimbulkan banyak pemikiran-pemikiran baru termasuk dalam hal keIslaman. Suatu penilaian ataupun evaluasi terhadap pemahaman keagamaan khususnya keIslaman sangat penting ntuk melihat kondisi manusia di era globalisasi.

Dalam hal ini, pembangunan dapat diartikan sebagai suatu upaya terkoordinasi untuk menciptakan alternatif yang lebih banyak secara sah kepada setiap warga negara untuk memenuhi dan mencapai aspirasinya yang paling manusiawi menurut Nugroho dan Rochmin Dahuri arti pembangunan adalah: Pertama, adalah terciptanya alternatif yang lebih banyak secara sah. Hal ini dapat diartikan bahwa pembangunan hendaknya berorientasi kepada keberagaman dalam seluruh aspek kehidupan. Ada pun mekanismenya 
menuntut kepada terciptanya kelembagaan dan hukum yang terpercaya yang mampu berperan secara efisien, transparan, dan adil. Kedua, untuk mencapai aspirasi yang paling manusiawi, yang berarti pembangunan harus berorientasi kepada pemecahan masalah dan pembinaan nilai-nilai moral dan etika umat. Kaum intelektual muslim menerima cita-cita dan ideologi nasional dan memanfaatkannya untuk melegitimasikan kegiatan mereka, yang tujuan sebenarnya adalah menyebarkan cita-cita Islam. Cita-cita nasional pembangunan ekonomi diterima oleh kaum intelektual muslim dan ditransformasikan menjadi tugas Islam baik melalui jihad atau teologi pembebasan. Kaum intelektual muslim menyatakan bahwa Islam mempunyai suara yang harus dihormati dalam urusan-urusan selaian perkara keagamaan semata.

Khususnya dua sila dari pancasila, yakni keadilan sosial dan demokrasi (permusyawaratan), menjadi bagian penting. Adanya reorienstsi kebijakan dan strategi pembangunan, di pusat dan daerah, yang lebih terpusat. Pembangunan manusia menjadi program yang selalu ada untuk diimpelemasikan demi menyiapkan kualitas manusia yang baik untuk mengisi sektor-sektor yang dapat menguntungkan lagi menghasilkan. Hal ini tentu harus direncanakan dan dipersiapakan secara matang dan sustainable atau berkelanjutan, sehingga dapat mencapai pada hasil serta tujuan yang telah diperhitungkan. Hal itu didukung oleh kenyataan bahwa keduanya adalah konsep-konsep Islam yang penting. Pembangunan adalah suatu kewajiban agama. Bukan hanya aspek-aspek tertentu agama Islam saja yang diajarkan, tetapi mereka juga terkait oleh keharusan untuk membangun kehidupan yang lebih baik. Lembaga-lembaga keagamaan mempunyai tugas yang penting untuk bekerja demi pembangunan manusia. Islam merupakan pemersatu kebanyakan maasyarakat Indonesia, pengembangan masyarakat tidak dapat di pisahkan dari program pendidikan Islam karena kegiatan pengembangan masyarakat adalah perwujudan dari konsep kewajiban manusia mengabdi kepada Allah. 
Pilar pembangunan manusia adalah istishlah atau kebaikan/kemaslahatan bagi manusia. Al-Quran secara eksplisit menjelaskan akan larangan untuk membuat kerusakan dimuka bumi, sehingga setiap kebijakan yang diputuskan oleh manusia harus memperhatikan pilar ini. Pelaksanaan pilar bangunan ini hanya memberikan dua rambu yaitu halal dan haram yang masing-masing memiliki konsekuensi yaitu pahala atau dosa. Jika semua kebijakan terhadap pembangunan manusia membawa kebaikan bagi kualitas hidup manusia maka hal tersebut halal dilakukan dan mereka berhak mendapatkan pahala karena telah menjalankan ketaatan terhadap perintah Allah swt sedangkan sebaliknya jika mereka membuat kebijakan yang dapat merusak kualitas hidup manusia maka hal tersebut haram dari sisi aturan dan dosa jika tetap dilakukan. Pada akhirnya, pembangunan kualitas manusia dengan menitikberatkan pada pembangunan keilmuan dan keimanan mampu menghasilkan generasi baru yang cerdas berilmu dan berkemajuan dan memiliki spirit keimanan dan tauhid kepada Allah swt. Sehingga Islam hadir pada setiap pola pikir masyarakat, pada setiap pengambilan keputusan, serta pada segenap lini kehidupan di masyarakat. Implikasi lebih jauh dari hal tersebut adalah terciptanya lingkungan serta kehidupan social-masyarakat yang baik dan beradab.

Kemampuan kejiwaan merupakan sumber daya insani (sumberdaya manusia) yang dimiliki oleh manusia. Dengan seperangkat organ tubuh yang diberikan oleh Allah swt kepada manusia, manusia mempunyai daya atau potensi (kekuatan) yang apabila dikembangkan akan menjadi sumber daya manusia yang berkualitas, dan akan menjadikan manusia yang sadar akan tanggung jawabnya baik tanggung jawabnya sebagai hamba Allah swt dan sebagai khalifah Allah swt. Manusia mempunyai sumber daya yang meliputi daya tubuh, daya hidup, dan daya akal. Apabila keempat daya tersebut dikembangkan, maka akan menjadi sumber daya manusia yang berkualitas dalam artian beriman, bertaqwa, berbudi pekerti luhur dan mampu menjalankan tugasnya sebagai hamba Allah swt dan sebagai khalifah Allah swt. 
Sebagaimana dalam hadits Rasulullah, Beliau bersabda : sesungguhnya bekerja mencari rezeki yang halal itu merupakan kewajiban setelah ibadah fardhu (HR. Tabrani dan Baihaqi). Dalam islam digunakan istilah kerja keras, kemandirian (biyadilu) dan tidak cengeng. Setidaknya terdapat beberapa ayat Al-Quran maupun hadists yang dapat menjadi rujukan pesan tentang semangat kerja keras dan kemandirian ini, seperti: Amal yang paling baik adalah pekerjaan yang dilakukan dengan cucuran keringatnya sendiri (HR. Abu Dawud). Islam memandang bahwa bekerja merupakan suatu kewajiban bagi setiap insan. Karena dengan bekerja seseorang akan memperoleh penghasilan yang dapat memenuhi kebutuhan hidup dirinya dan juga keluarganya serta dapat memberikan maslahat bagi masyarakat disekitarnya. Islam juga mengajarkan bahwa pekerjaan harus dilaksanakan oleh orang yang mengetahuinya dengan ilmu atau dengan ilmu atau dengan kata lain pekerjaan harus dikerjakan oleh orang yang ahli dibidangnya. Hal ini ditegaskan dalam Al-Quran dalam Firmannya : “...dan janganlah kamu mengikuti apa yang kamu tidak mempunyai pengetahuan tentangnya. Sesungguhnya pendengaran, penglihatan dan hati, semuanya itu akan diminta pertanggung jawabnya”. (QS: Al-Israa'[17] : 36). Allah mengingatkan manusia agar mencegah keburukan dengan tidak berucap apa yang tidak diketahui, jangan mengaku tahu apa yang engkau tidak ketahui, jangan mengaku tahu apa yang engkau tidak ketahui, termasuk dalam hal ini mengaku punya pengetahuan atau kompetensi di suatu bidang padahal dia tidak memilikinya. Ayat ini menuntun manusia jika bekerja menggunakan pendengaran, penglihatan dan hati sebagai alat-alat untuk meraih pengetahuan.

Pembahasan dalam Islam sosok manusia terdiri dua potensi yang harus dibangun, yaitu lahiriah sebagai tubuh itu sendiri dan ruhaniyah sebagai pengendali tubuh. Pembangunan manusia dalam Islam tentunya harus memperhatikan kedua potensi ini. Jika dilihat dari tujuan pembangunan manusia Indonesia yaitu menjadikan manusia seutuhnya, maka tujuan tersebut harus memperhatikan kedua potensi yang ada pada manusia. Islam 
memandang tinggi masalah sumberdaya manusia ini khususnya yang berkaitan dengan akhlak (sikap, pribadi, etika dan moral). Kualitas sumberdaya manusia menyangkut banyak aspek, yaitu aspek sikap mental, perilaku, aspek kemampuan, aspek intelegensi, aspek agama, aspek hukum, aspek kesehatan dan sebagainya. Tidak dapat dipungkiri bahwa aspek jasmaniah selalu ditentukan oleh ruhaniah yang bertindak sebagai pendorong dari dalam diri manusia. Untuk mencapai sumberdaya manusia berkualitas, usaha yang paling utama sebenarnya adalah memperbaiki potensi dari dalam manusia itu sendiri, hal ini dapat diambil contoh seperti kepatuhan masyarakat terhadap hukum ditentukan oleh aspek ruhaniyah ini.

\section{ANALISIS TERHADAP ISLAM DAN PEMBANGUNAN MANUSIA DI INDONESIA}

Saat ini dunia memang sedang berada di tengah globalisasi, yaitu suatu era yang melahirkan saling ketergantungan antara negara satu dengan negara yang lainnya, sehingga menuntut adanya kerjasama yang erat untuk membangun kehidupan masing-masing negara. Globalisasi juga telah merubah peran dan fungsi negara dengan menyesuaikan realitas baru yang muncul di dunia, hal ini dikarenakan globalisasi akan berjalan dengan baik bila negara tetap berperan aktif didalamnya dan sisesuaikan dengan realitas baru yang muncul di dunia. Ini menandakan bahwa globalisasi tidak menghapuskan peran negara karena adanya manfaat globalisasi yang hanya dapat dinikmati oleh masyarakat apabila negara ikut berperan aktif didalamnya sesuai dengan tangung jawabnya.

Eksklusi perempuan, etnis minoritas, dan orang-orang yang tinggal di daerah terpencil menghambat kemajuan pembangunan manusia. Hal ini telah menyebabkan kesenjangan yang signifikan dan menyebabkan banyak ketertinggalan di dunia, termasuk di Indonesia dan kawasan Asia dan Pasifik. Selain itu, kelompok yang termarjinalisasi sering memiliki kesempatan terbatas untuk mempengaruhi lembaga dan kebijakan yang menentukan hidup 
mereka. Ini adalah salah satu temuan kunci yang dilakukan oleh United Nations Development Programme (UNDP).

Pembangunan Manusia untuk semua aspek mengadvokasikan fokus yang lebih besar pada kelompok tereksklusikan, dan tindakan untuk mengatasi hambatan inklusi sangat diperlukan untuk memastikan pembangunan manusia berkelanjutan untuk semua orang. Menurut Selim Jahan, jangan terlalu berfokus pada rata-rata nasional, yang sering menutupi variasi yang sangat besar dalam kehidupan masyarakat. Untuk maju perlu meneliti lebih dekat bukan hanya apa yang telah dicapai, tetapi siapa yang telah tertinggal dan mengapa bisa terjadi. Dalam analisisnya tersebut, menunjukkan bahwa kemajuan belum memberi manfaat bagi semua orang dan kesenjangan berdampak pada kelompok tertentu secara tidak proporsional. Terutama perempuan, etnis minoritas dan orang-orang yang tinggal di daerah terpencil dapat mengalami deprivasi secara terbuka dan tersembunyi. Di Indonesia, meskipun terjadi penurunan kemiskinan secara tajam dalam dua dekade terakhir, 140 juta warga masih hidup dengan kurang dari Rp. 20.000 per hari.

Indeks Pembangunan Manusia Indonesia (IPM) untuk 2015 adalah 0.689. Ini menempatkan Indonesia dalam kategori pembangunan manusia menengah, dan peringkat 113 dari 188 negara dan wilayah. Nilai IPM meningkat 30,5 persen dari nilai pada tahun 1990. Hal ini mencerminkan kemajuan yang telah dicapai Indonesia dalam hal harapan hidup saat lahir, rata-rata tahun bersekolah, harapan lama bersekolah dan pendapatan nasional bruto (PNB) per kapita selama periode tersebut. Menurut Christophe Bahuet, menunjukkan bahwa setelah begitu banyak kemajuan yang dicapai oleh Indonesia, langkah selanjutnya menuju pembangunan manusia yang tinggi adalah inklusi dan pengurangan kesenjangan, khususnya untuk provinsi terpencil dan antara laki-laki dan perempuan.

Perkembangan globalisasi membawa dampak yang teramat luas, baik dampak positif maupun dampak negatif. Kualitas masyarakat yang baik sangat dibutuhkan untuk dapat bertahan dan turut mengendalikan 
perkembangan global ke arah yang baik. Masyarakat yang berkualitas tinggi ditunjukkan dengan kemampuan berliterasi sains yang baik meliputi kemampuan berpikir kreatif, menganalisis masalah, mengambil keputusan, bersikap dan menyelesaikan masalah. Namun, untuk membendung dampak negatif perkembangan global tidak cukup dengan kemampuan literasi sains tetapi juga butuh kemampuan literasi Islam yang baik. kemampuan berliterasi Islam yang baik sebagai bentuk rasa syukur kepada Allah SWT, meliputi pemahaman nilai-nilai tauhid uluhiyah dan tauhid rububiyah. Keseimbangan dalam pembangunan manusia berdasarkan kedua ranah ini merupakan aspek penting untuk menghasilkan manusia Indonesia yang beradab, berkepribadian dan berkemajuan.

\section{OUTPUT DARI KONSTRUKSI ISLAM DAN PEMBANGUNAN MANUSIA}

Implikasi pembangunan manusia dalam perspektif Islam adalah multi-dimensi yang meliputi aspek spiritual, sosial, manajerial, vertikal, horizontal, dan emosional dalam intelektual. Manusia yang merupakan khalifah bertanggungjawab untuk membangun alam semesta menuju kehidupan dengan nilai-nilai pembaharuan dan kemajuan. Hasilnya dari segi fungsional, pembangunan memiliki persamaan antara model pembangunan manusia perspektif Islam dengan pembangunan manusia perspektif konvensional. Hal tersebut dapat diimplementasikan dalam setiap agenda maupun program pengembangan manusia menuju manusia yang memiliki produktivitas yang tinggi, progresivitas yang besar, dan spitualitas yang harmonis. Peningkatan, pengembangan sekaligus pengaplikasian terhadap pembangunan manusia menemukan integrasi nilai terhadap moralias manusia di era globalisasi.

Pembangunan manusia melalui penerapan antara Islam dengan Manusia di era globalisasi bertujuan untuk mengahdirkan manusia yang berkualitas, beriman, bertakwa, berkemajuan, dan beradab di tengah modernisasi. Hal tersebut untuk dapat memiliki daya saing, daya daya pikir, 
daya juang, dan daya kepemimpinan untuk mengisi pembangunan di segala aspek kehidupan yang didasari oleh modal pondasi manusia. Islam memandang bahwa manusia dapat bergerak secara dinamis, yang artinya cepat menyesuaikan diri dengan situasi, keadaan, dan perkembangan yang ada untuk terus berkembang. Islam juga memandang bahwa manusia dapat tercipta secara humanis, yang artinya menerapkan nilai kemanusiaan, kepeduliaan dalam menjunjung tinggi toleransi sebagai bentuk harmonisasi kehidupan. Islam hadir untu menjadikan manusia memiliki moralitas ataupun akhlak secara agamis, yang artinya setiap aktivitas kehidupan selalu berorientasi pada nilai, integrasi sosial dan spiritual kerohanian sebagai prinsip dasar yang menjadi pondasi utama untuk menyambut konteks pembangunan.

\section{KESIMPULAN}

Pembangunan manusia memiliki dimensi yang sangat luas dan cenderung kompleks. Simplifikasi dari kompleksitas ini, diwujudkan dengan menampilkan sumberdaya manusia dan pembangunan manusia sebagai ukuran pembangunan yang komprehensif, yang akan dioptimumkan pemanfaatannya dalam evaluasi pembangunan, alat advokasi, maupun perumusan kebijakan perencanaan pembangunan. Kebijakan pembangunan pada masa mendatang akan sangat dipengaruhi oleh paradigma pembangunan manusia yang saat ini sedang berkembang, sejalan dengan berkembangnya tuntutan reformasi dan situasi krisis. Kebijakan pembangunan manusia yang responsif, harus memperhatikan 4 hal pokok, yaitu peningkatan produktivitas penduduk, pemerataan kesempatan untuk setiap penduduk, kesinambungan untuk generasi mendatang, dan pemberdayaan masyarakat partisipasi aktif masyarakat sipil juga sangat diperlukan dalam proses pembangunan negara baik di tingkat pusat maupun daerah provinsi, kabupaten/kota, distrik dan kampung. Hal ini menuntut kesadaran dan semangat masyarakat sipil seutuhnya sebagai warga Negara yang turut bertanggung jawab dalam proses pembangunan. Berdasarkan kesimpulan di atas, maka solusi alternatif yang dapat dipaparkan adalah sebagai berikut: Pertama, pembangunan 
mansia yang merupakan bagian penting dalam mencerdasakan kehidupan bangsa maka perlu adanya reformasi program-program berkaitan dengan SDM. Upaya reformasi ini termasuk bentuk transformasi segala kegiatan pemberdayaan dan pengembangan sumber daya manusia secara mearata baik secara ekonomi, pendidikan dan kesehatan. Kedua, optimalisasai potensi sumber daya manusia yang prestatif, progersif dan produktif untuk masuk ke sektor-sektor strategis sebagai bentuk bagian keberlanjutan sekaligus sinergitas dalam mengelola SDM dengan baik. Ketiga, evaluasi kinerja setiap unsur SDM di berbagai aspek yanga ada untuk melakukan perubahan secara efektif dan efisien. Evaluasi SDM merupakan bagian untuk mengukur tingkat produktivitas manusia dan progreisivitas manusia dalam menghadapi kemajuan di era globalisasi.

\section{DAFTAR PUSTAKA}

Badruddin, Syamsiah. (2009). Teori dan Indikator Pembangunan. Jakarta: Yayasan Obor. Badan Pusat Statistik (BPS). (2018). Statistik Tahunan. Berbagai Tahun Penerbitan URL http://www.bps.go.id/.html.

Davies, A. and G. Quinlivan. (2006). A Panel Data Analysis of the Impact of Trade on Human Development, Journal of Socioeconomics.

Dunstan, Isabel. (2018). Indeks Pembangunan Manusia Indonesia Meningkat tapi Kesenjangan Masih Tetap Ada. URL http://id.linkedin.com/in/isabeldustan.

Giddens, Anthony. (2000). The Third Way, Jalan Ketiga: Pembaharuan Demokrasi Sosial, Jakarta: Gramedia Pustaka Utama.

Kencana Syafiie, Inu. (2002). Sistem Pemerintahan Indonesia. Jakarta: Rineka Cipta. Kumalasari, Merna. (2011). Analisis Pertumbuhan Ekonomi, Angka Harapan Hidup, Angka Melek Huruf, Rata-rata lama sekolah, Pengeluaran Perkapita, dan Jumlah Penduduk Terhadap Tingkat Kemiskinan Di Jawa Tengah. Fakultas Ekonomika Dan Bisnis, Universitas Diponegoro Semarang.

Jakson, Robert Dan George Sorensen. (2009). Pengantar Studi Hubungan Internasional. Yogyakarta: Pustaka Pelajar.

Maqin, Abdul. (2007). Indeks Pembangunan Manusia: Tinjauan Teoritis, Empiris di 
Jawa Barat (Makalah Pelatihan Program pendanaan Kompetisi Indeks Pembangunan Manusia PPK-IPM).

Mullis, IVS., Martin, MO., Foy, P. (2011). TIMSS 2011 International Results in Mathematics. TIMSS \& PIRLS International Study Center, Lynch School of Education, Boston College.

Miharja, Fuad Jaya. (2015). Peran Media Pembelajaran Islam dalam Mengembangkan Kualitas Pendidikan Nasional di Era Global. Prosiding Seminar Nasional Pendidikan Reformasi Pendidikan dalam Asean Economic Community (AEC) di FKIP Universitas Jember.

Nasution, Zulkarimen. (2007). Komunikasi Pembangunan (Pengenalan Teori dan Penerapannya). Jakarta: PT. Raja Grafindo Persada.

Sukirno, Sadono. (1982). Beberapa Apek Dalam Persoalan Pembangunan Daerah. Jakarta: Fakultas Ekonomi Universitas Indonesia.

Sukma. (2018). Islam Pembangunan. URL http://www.wordpress.com.html.

Thompson, S., Provasnik, S., Kastberg, D., Ferraro, D., Lemanski, N., Roey, S., and Jenkins, F. (2012). Reading Achievement of U.S. Fourth-Grade Students in an International Context (NCES 2013-010 Revised). National Center for Education Statistics, Institute of Education Sciences, U.S. Department of Education. Washington, DC. Government Printing Office, Highlights From PIRLS.

T, Moeljarto. (1995). Politik Pembangunan (Sebuah Analisis Konsep, Arah dan Strategi). Yogyakarta: PT. Tiara Wacana Yogya.

Yudi, Alex Aldha. (2012). Pengembangan Mutu Pendidikan Ditinjau dari Segi Sarana dan Prasarana (Sarana dan Prasarana PPLP). Jurnal Cerdas Sifa Vol.1.No.1. Mei-Agustus. 